\title{
Ernő Foerk And the Medieval Cathedrals of Kalocsa
}

\author{
Béla Zsolt Szakács \\ Department of Art History, Pázmány Péter Catholic University, Budapest, Hungary \\ szakacsb@btk.ppke.hu
}

\begin{abstract}
The restoration of the Baroque cathedral of Kalocsa was led by Ernö Foerk between 1907 and 1912. During these years the facades of the church were renewed, a Neo-Baroque ambulatory was added, and excavations were carried out within the sanctuary and in front of the south facade. Based on these excavations, Ernö Foerk published theoretical reconstructions of the first and second medieval cathedrals and criticised the results of the previous research, conducted by Imre Henszlmann. Foerk, being also a scholar of the history of architecture, based his results on analogies. This paper intends to point out the elements which are outdated in the reconstruction of Foerk and his methodology that is still relevant.
\end{abstract}

Keywords: Kalocsa, Ernö Foerk, restoration of historic buildings, Ottonian architecture, Gothic architecture

Ernő Foerk, together with Gyula Petrovácz, built and renewed a number of churches in the territory of the Archbishopric of Kalocsa after 1905. [1] The commissioner was Archbishop Gyula Városy, leading the archdiocese of Kalocsa between 1905 and 1910. Városy was a learned scholar, active as the archivist of the archdiocese from 1875 and leading the library of the archbishopric after 1878. [2] As such, he also compiled a study on Astrik, the first archbishop of Kalocsa in Latin. [3] Obviously, his interest towards the past of the archdiocese and the person of Astrik was still vivid during the period when he served as archbishop of Kalocsa.

On the initiative of Gyula Városy, the cathedral of Kalocsa was restored between 1907 and 1911 by Ernő Foerk and Gyula Petrovácz, spending 330.000 Austro-Hungarian Crowns. [4] The Archbishop commissioned Foerk in August of 1906. [5] Foerk submitted the restoration plans in the next summer; [6] however, there were debates on the subject within the chapter which caused delays. [7] In early 1908 the plans were submitted to the National Committee of Historic Monuments (Mủemlékek Országos Bizottsága), [8] which decided positively by the end of this year. [9] Foerk received the final commission for detailed restoration plans in September 1909 [10] which were ready by March 1910 when the actual works have been started. [11] The restored cathedral was benedicted on $4^{\text {th }}$ October 1911. [12]

During the restoration, the aim was to return to the Baroque state of the cathedral. The western façade was cleaned, the coat of arms of the original builder, Archbishop Gábor Patachich (17331745) was moved to one stores up, replacing it by the relief of the Holy Virgin, title saint of the cathedral, to whom Saint Stephen, first king of Hungary (997-1038) offers his royal crown, brought to Hungary by Archbishop Astrik. More important changes were done in the chancel. The Neo-Romanesque high altar, commissioned by Arhcbishop József Kunszt (1852-1866), was replaced by a Neo-Baroque baldachin, The original Baroque façade of the chancel proved to be too simple therefore a new ambulatory was built between the two original sacristies.

This addition was built on the fundaments of the ambulatory of the medieval cathedral. 
Within the choir, a new archbishopric crypt was established in 1910, serving up to now as the burial site of the leaders of the archdiocese. During the building of the new crypt, archaeological investigations were also done. A red marble sarcophagus was found with a male skeleton and bishopric insignia inside. [13] For Enrő Foerk it was evident that he found the tomb of Archbishop Astrik from the eleventh century, and there are recent attempts to follow this hypothesis based on recent scientific methods. [14]

For our purpose, it is more important that around the tomb the fundaments of the first cathedrals were revealed. Before 1910, there were no excavations within the building. In 1869, Imre Henszlmann carried out archaeological research outside of the church with the permission and support of Archbishop Lajos Haynald (1867-1891). [15] Although never excavating within the building, Henszlmann reconstructed the first cathedral as a single-nave building with as semi-circular apse, and pairs of tower at the east and at the west. Large remains of the western towers were identified by Henszlmann during his research.

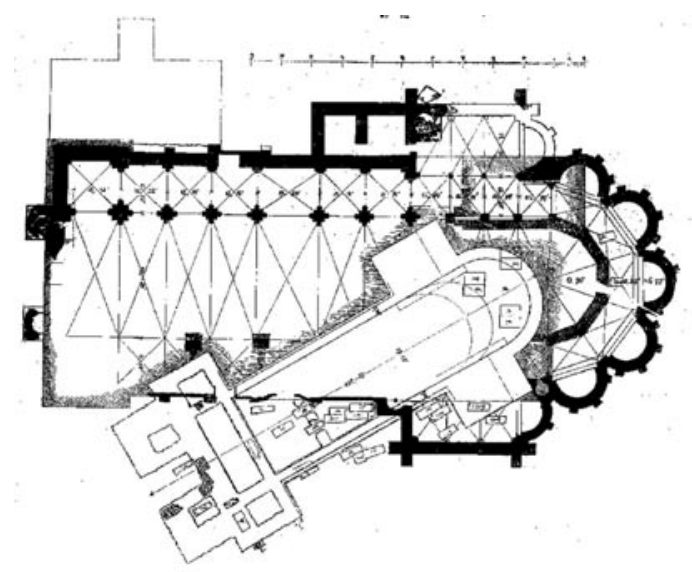

Figure 1. Kalocsa I and II according to the reconstruction of Imre Henszlmann

The researches of Ernő Foerk verified the hypothesis of Henszlmann regarding the semicircular apse, however, contradicted to his other assumptions. According to Foerk, the nave was three-aisled, and instead of western towers, it had an atrium and a narthex. [16] His ideas originate from an architecture historical conception. Replacing the bizarre fourtower reconstruction of Henszlmann, Foerk applied the well-known architectural type of the three-aisled Early Christian basilica with an atrium.

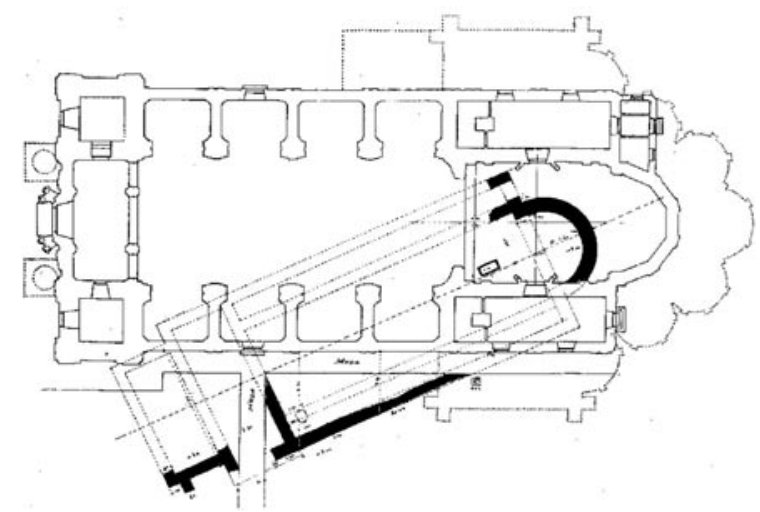

Figure 2. Kalocsa I according to the excavations of Ernő Foerk 
The reconstruction drawing published by Foerk, however, is problematic. First of all, the proportions of the atrium are strange: this is a rectangular space instead of the usual quadrate format, providing practically no space for the uncovered courtyard. Moreover, there is and architectural detail discovered during the excavation (and indicted in the archaeological ground plan), a fragment of a wall on the south side of the atrium, which is missing from the reconstruction drawing.

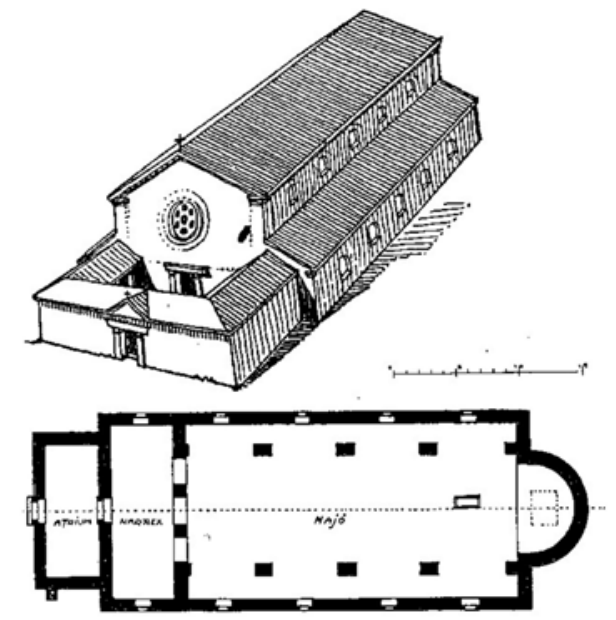

Figure 3. Kalocsa I according to the reconstruction of Ernő Foerk

Thus, the reconstructions of Henszlmann and Foerk seem to be radically different for the first sight. However, projecting the two ground plans above each other, it turns out that in reality they discovered the same fragment but interpreted them differently. [17] The major difference between the two drawings is the axis: according to Foerk, the axis of the first cathedral was closer to the regular east-west axis. Consequently, what Henszlmann interpreted as the wall of the nave, was regarded by Foerk as the wall of the southern aisle. Similarly, the fragments of the narthex and atrium of Foerk are identical with those of Henszlmann's western complex. Revealing this, we can see now the original purpose of the wall fragment on the south side eliminated by Foerk: this is a section of the south tower of Henszlmann. Thus, opposed to the original intentions of Foerk, his excavations verified the results of Henszlmann.

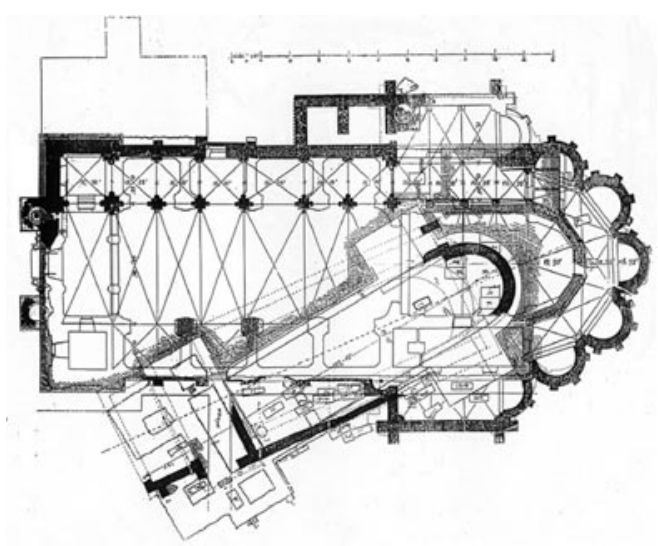

Figure 4. The relationship of the ground plans of Henszlman and Foerk 
Obviously, the problem can be solved only with a new excavation. Connected to the recent restorations of the cathedral of Kalocsa, there are new excavations carried out since 2014 within and around the church. In the year 2014 the excavations were led by Gergely Buzás in the interior, the results of which is indicated in his drawing. [18] This drawing supports the singlenave concept and takes over the suggestions of Henszlmann regarding the south-east addition as well as the western parts. We must know that in 2017-18 there were new excavations at the western side of the first cathedral, however, the results have not been published yet.

Thus, according to our present knowledge, the first cathedral of Kalocsa was a single-nave building with a semi-circular apse. There were additional rooms on both sides of the chancel, of which the southern one was already identified by Henszlmann (also accepted by Buzás), while the northern one is proved by a wall fragment found by Foerk (but missing from the drawing of Buzás). [19] On the west, a complex architectural structure was added maybe somewhat later (the chronology has not been clarified yet [20]): a space, divided from the nave, was flanked by additional rooms from the south and the north, while west of it an open entrance hall and pair of towers can be identified. This description fits world by world to the second phase of the church of St Pantaleon of Cologne, dating from around 1000, which was the burial place of Empress Theophanu, the widow of Otto II and mother of Otto III. [21] I do not state that there was a direct connection between Cologne and Kalocsa (although it cannot be excluded) but it seems to be evident that the cathedral of Kalocsa followed an architectural type well-known in Ottonian architecture.

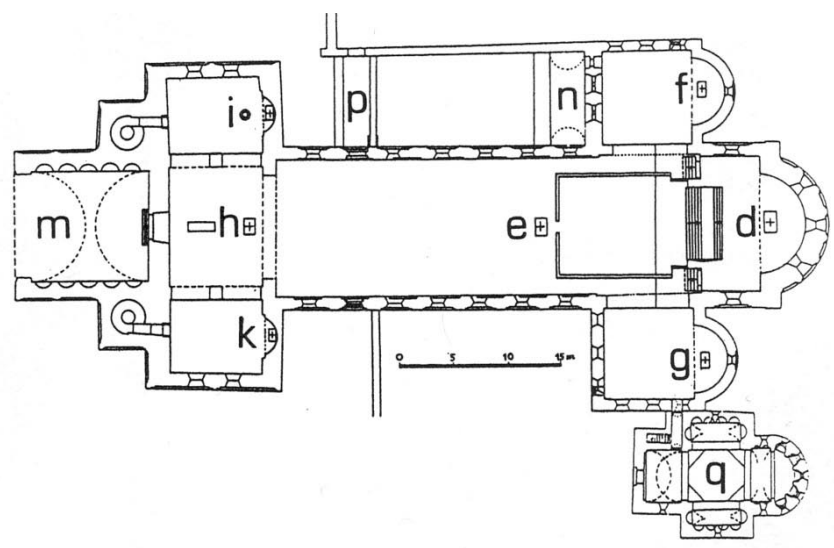

Figure 5. The ground plan of St Pantaleon II in Cologne

During his researches, Ernő Foerk was also dealing with the second medieval cathedral of Kalocsa. [22] Its perimeter walls have already been discovered by Henszlmann. According to the reconstruction of Foerk, this building followed the bound system (gebundenes System) with alternating supports. It had a transept with an apse and an ambulatory with radiating chapels, all of them with semi-circular forms. The reconstruction drawings of Foerk represent a typical Romanesque church with a crossing tower, portals decorated with jambs, rose windows and small round turrets. 

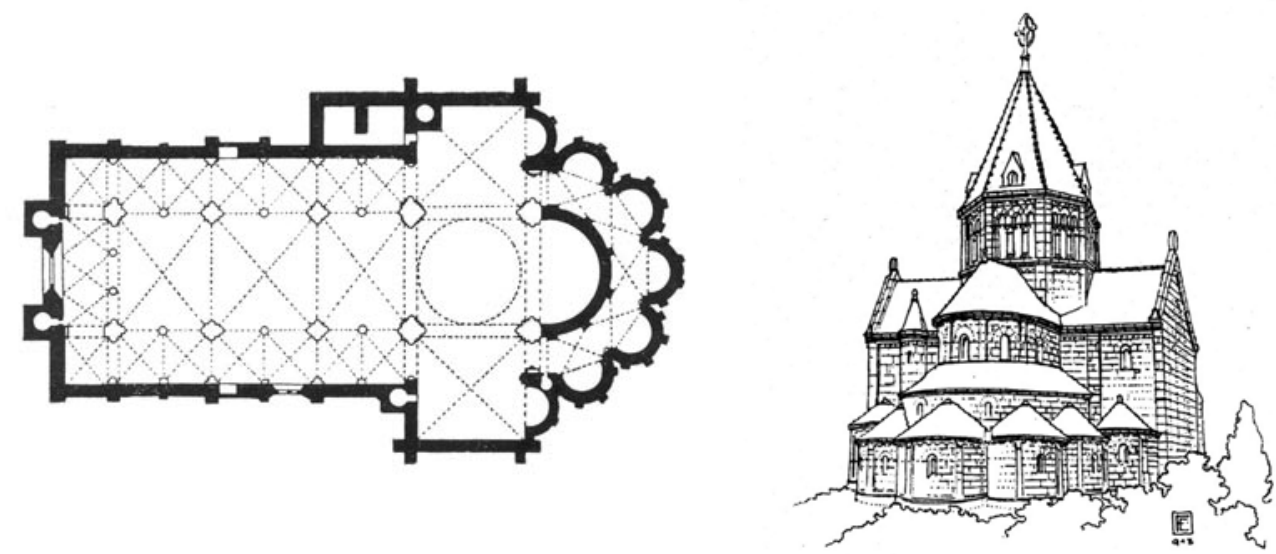

Figure 6. Kalocsa II according to the reconstruction of Enrő Foerk

Foerk pointed out that the closest analogy of this ground plan can be found in South-Western France in the Benedictine priory church of Avesnières (now part of Laval town), where on the site of an earlier church, the still standing building dates from the twelfths century. The similarity is so obvious that Foerk suggested direct connection. According to his assumption, the master of this church, built in 1140-47, must have participated in the crusader army of King Louis VII of France, which passed Hungary in 1148. Thus the knowledge of the French architect could have been used in Kalocsa, too.
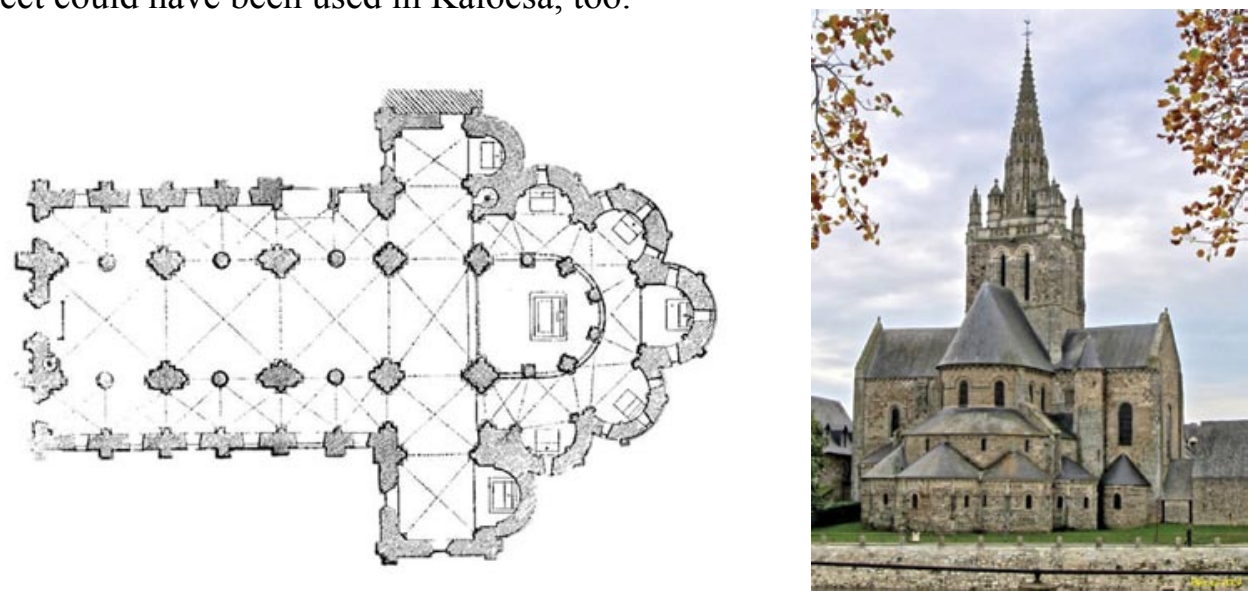

Figure 7. The ground plan and eastern view of the priory church of Avesnières

The similarity is really breath-taking; however, this results from the fact that the reconstructions of Foerk are in fact based on the church of Avesnières. It is less important for us that the French building is the result of a longer creation process and only the eastern parts date form around 1140 while the transept is from 1170, the nave being drastically restored at the end of the nineteenth century. [23] It is more significant to underline that the reconstruction of Foerk was intentionally invented against the ideas of Henszlmann. According to the assumption of Henszlmann, the second cathedral of Kalocsa was built in the first half of the thirteenth century commissioned by Archbishop Ugrin (1219-1241). Opposed to this suggestion, Foerk established again an architectural historical conception. With the semi-circular forms of the apses and ambulatory and with the bound system he classified the building as typically Romanesque. 
He also drew the conclusions: if a church with ambulatory was built in Hungary around 1150, then it is earlier than anything in Germany where the first ambulatory was applied at the St Godehard of Hildesheim, finished in 1172. [24]

It seems that this concept of Foerk is outdated, too. According to recent scholarship, the polygonal apse and ambulatory is more probable. [25] This has been proven by the newest excavations. It became evident that the polygonal walls of the Baroque apse are standing on the medieval fundaments, its pilasters replacing the medieval responds. This detail has an important consequence: polygonal apses with semi-circular radiating chapels are known from Early Gothic churches. This is in accordance with the stone carvings which prove the connections of Kalocsa with such important Early Gothic architectural centres of Hungary as Esztergom, the Cistercian Abbey of Pilis or the Abbey of Vértesszentkereszt. Based on this observation, the dating of the second cathedral Kalocsa should be moved to the early thirteenth century, in the period of Archbishop Berthold (1206-1219, brother-in-law of King Andrew II) or Archbishop Ugrin.

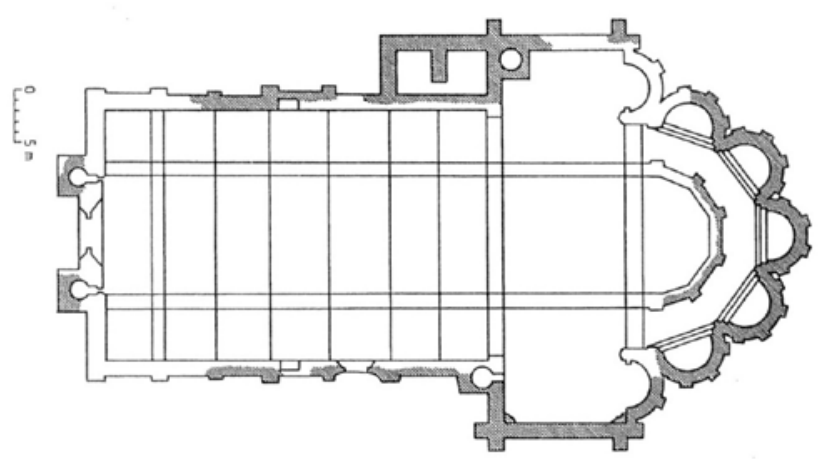

Figure 8. Kalocsa II according to the reconstruction of Ernő Marosi

What is the final conclusion of all these observations? Ernő Foerk was a learned architect, an architectus doctus, dealing professionally with the history of architecture. This is proved by his publication activity, including the monography of the cathedrals of Kalocsa printed in 1915, [26] the analysis of the architectural types of Romanesque churches of Hungary from 1926 [27] or the overview of the history of Hungarian architecture dating from 1929. [28] Foerk rightly criticised the old, outdated conceptions of Imre Henszlmann, formulated a half century before. According to Henszlmann, Hungarian architecture followed Germany and France but only with 50 or 100 years delay. Opposed to this idea, Foerk compared Hungarian churches to the contemporaneous buildings and argued that their prototypes can be found in Italy (as that of the first, Early Christian type cathedral) or in France (as that of the second cathedral). Even in this case Hungary must have preceded Germany.

Although according to our present knowledge, none of the hypotheses of Foerk can be accepted, since the first cathedral followed Ottonian models while the second was built in Early Gothic style at the beginning of the thirteenth century. Nevertheless, he was right in his general perception. Monuments of Hungarian architecture should be compared to architectural tendencies of their own age, revealing their real significance. That is clear in the case of Kalocsa and Foerk correctly realized its significance. The first cathedral is comparable to the most modern imperial buildings of the leading power of Europe while the second cathedral was the first and only Early Gothic cathedral in East Central Europe, which was followed only a century later. 


\section{REFERENCES}

[1] Foerk, E., Petrovácz, Gy., A kalocsai érseki főegyházmegye újabb templomépítkezései 1907-1911, Kalocsa: Élet Ny., 1912.

[2] Magyar katolikus lexikon XIV. (Titel-Veszk). General ed. Dıós, I.; ed. Viczián, J., Budapest: Szent István Társulat, 2009, htтP://LeXikon.KATOLikUS.hu/V/V\%C3\%A1rosy.hTML

[3] V'́rosy, Gy., Astricus sedi suae Colocensi servatus, Kalocsa, 1879

[4] FoErK, E., A kalocsai székesegyház, Magyarország Müemlékei IV (1915), 43-70.

[5] Diary of Ernő Foerk (a type-written copy is available in the Hungarian Architectural Museum), 31., 02/08/1906.

Foerk visited the Archbishop in September personally and started to measure the cathedral with Petrovácz, ibidem, 20-

23/09/1906. I wish to express my gratitude to Eszter Baldaváry and the Museum for their help during my research.

[6] Diary, op. cit. 34., 26/07/1907.

[7] Diary, op. cit. 35., 31/12/1907.

[8] Diary, op. cit. 36., 28/02/1908.

[9] Some modifications were discussed between Frigyes Schulek and Ernő Foerk. Diary, op. cit. 38., 28-29/12/1908.

The minutes were verified by Foerk on 15/01/1909.

[10] Diary, op. cit. 40., 29/09/1909.

[11] Diary, op. cit. 42., 1-/03/1910. On 28 March Foerk travelled to Kalocsa where the works have been started on 29/03/1910.

[12] Diary, op. cit. 49., 4/10/1911. Archbishop Városy died in the previous year therefore the festive mass was celebrated by the new archbishop, János Csernoch (1911-1913).

[13] FoErK, E., A kalocsai Szt.-Istvánkori székesegyház érseki sírja, Archaeologiai Értesitő 31 (1911), 19-33.

[14] Buzás, G., A kalocsai érseskír azonosítása. Archaeologia - Altum Castrum 2014. http://pannonhalma70-74.gportal.hu/ portal/pannonhalma70-74/upload/251068_1397808574_08875.pdf. The majority of previous research regarded the tomb as that of Archbishop Saul (1192-1201).

[15] Henszlmann, I, Die Grabungen des Erzbischof von Kalocsa Dr. Ludwig Haynald, Leipzig, 1873; cf.. László, G. M., Henszlmann Imre és a kalocsai székesegyház 1869-es régészeti feltárása, in: Kalocsa történetéböl. Ed. KoszTA, L., Kalocsa: Kalocsa Város Önkormányzata, 2000, 75-95.

[16] FoERK op.cit. 1915, 49-51.

[17] For the comparison of the two ground plans, see LÁszLó op.cit. 92. and SZAKÁCs, B. Zs., Az államalapítás korának építészete Magyarországon, Müemlékvédelem 44 (2000), 67-74.: 68.

[18] Tóтн, E., Buzás, G., Magyar építészet I. . A rómaiaktól Buda elfoglalásáig, Budapest: Kossuth, 2016, 58.

[19] FoERK op.cit. 1915, 50, fig. 71.

[20] This part of the building is dated to the second third of the 11th century by BuzÁs op.cit. 2016, 58.

[21] Kоsсн, C., Überlegungen zu vorromanischen Westwerken und ihrer in der Stauferzeit veränderten Gestalt und Funktion (Ausgehend von St. Pantaleon in Köln), in: Kunst und Liturgie im Mittelalter. Ed. Bock, N. et al. (Römisches Jahrbuch der Bibliotheca Hertziana, Beiheft 33), München: Hirmer, 1999/2000, 101-120.

[22] FoERK op.cit. 1915, 51-62.

[23] Prieuré de bénédictines, église paroissiale Notre-Dame, basilique Notre-Dame-d'Avénières, notice no IA53000047, Base Mérimée, Ministère français de la Culture, http://www2.culture.gouv.fr/public/mistral/merimee_fr?ACTION= CHERCHER\&FIELD_1=REF\&VALUE_1=IA53000047; Basilique Notre Dame d'Avesnières, Diocèse de Laval, http://archive.wikiwix.com/cache/?url=http\%3A\%2F\%2Fwww.diocese-laval.fr\%2Fparoisses\%2Fla-trinite-avesnierescordeliers\%2Fet-aussi\%2F4552-decouvrez-la-basilique-notre-dame-d-avesnieres.html; https://commons.wikimedia.org/ wiki/File:Plan_basilique_Avesni\%C3\%A8res.svg

[24] FOERK op.cit. 1915, 56.

[25] Marosı, E., A második kalocsai székesegyház néhány művészettörténeti kérdése, in: Kalocsa történetéböl.

Ed. KoszTA, L., Kalocsa: Kalocsa Város Önkormányzata, 2000, 51-68.; TAKÁcs, I., Egy eltünt katedrális nyomában Újabb töredékek a 13. századi kalocsai székesegyházból, in: A középkori Dél-Alföld és Szer. Ed. KolLÁR, T., Szeged: Csongrád Megyei Levéltár, 2000, 305-336.

[26] FoERK op.cit. 1915.

[27] FoERK, E., Árpádkori templomaink típusai, A Magyar Mérnök- és Épitész-Egylet Közlönyének Havi Füzetei 3 (1926), 113-127.

[28] FoERK, E., A magyar építőművészet rövid története, Kecskemét: edition of the author, 1929. 